\title{
Implementasi Pembelajaran Tematik dalam Pembelajaran Daring Kelas IV SD
}

\author{
Nur Ainy*, Suhartono, Siti Mas'ula \\ Universitas Negeri Malang, Jl. Semarang No. 5 Malang, Jawa Timur, Indonesia \\ *Penulis korespondensi, Surel: iinainy19@gmail.com
}

Paper received: 6-8-2021; revised: 20-8-2021; accepted: 28-8-2021

\begin{abstract}
This research aims to determine the implementation and barriers of thematic learning encountered by 4 th grade teachers in planning, implementing, and evaluating aspects in online learning due the COVID-19 pandemic. The approach used in this research was descriptive quantitative by using expost facto method. The subject in this research was 94 samples, of which 4 teachers and 90 students. The results of this research indicate that: (1) the thematic lesson plan (RPP) was in fairly good quality with medium qualification $(79,89$ percent); (2) the learning implementation was in good quality with high qualification (91,49 percent); (3) the learning evaluation was in good quality with high qualification (74,80 percent); (4) there was a relationship between student outcomes and the lesson plan with a significance value (0.042 less than 0.05); (5) there was a relationship between student outcomes and the learning implementation with a significance value (0.045 less than 0.05$)$; and (6) there was a relationship between student outcomes with the lesson plan and learning implementation with a significance value (0.045 less than 0.05$)$.
\end{abstract}

Keywords: thematic learning; online learning; elementary school

\begin{abstract}
Abstrak
Penelitian ini bertujuan untuk mengetahui penerapan dan hambatan pembelajaran tematik yang ditemui guru kelas IV SD di Gugus 3 Kedungkandang pada aspek perencanaan, pelaksanaan, dan evaluasi pembelajaran dalam pembelajaran daring selama masa pandemi COVID-19. Pendekatan yang digunakan pada penelitian ini yaitu kuantitatif deskriptif dengan metode ex-post facto. Subyek meliputi 94 sampel, di antaranya 4 guru dan 90 siswa. Hasil penelitian ini menunjukkan bahwa: (1) perencanaan pembelajaran tematik (RPP) berkualitas cukup baik dengan kualifikasi sedang $(79,89$ persen); (2) pelaksanaan pembelajaran tematik berkualitas baik dengan kualifikasi tinggi $(91,49$ persen); (3) evaluasi pembelajaran tematik berkualitas cukup baik dengan kualifikasi sedang $(74,80$ persen); (4) terdapat hubungan antara hasil belajar siswa dengan perencanaan pembelajaran, dengan nilai signifikansi $(0,042$ kurang dari 0,05$)$; (5) terdapat hubungan antara hasil belajar siswa dengan pelaksanaan pembelajaran, dengan nilai signifikansi (0,045 kurang dari 0,05); (6) terdapat hubungan antara hasil belajar siswa dengan perencanaan pembelajaran dan pelaksanaan pembelajaran dengan nilai signifikansi $(0,045$ kurang dari 0,05$)$.
\end{abstract}

Kata kunci: pembelajaran tematik; pembelajaran daring; SD

\section{Pendahuluan}

Pandemi COVID-19 (Coronavirus Disease) merupakan krisis kesehatan yang memberikan dampak besar bagi seluruh sektor kehidupan, salah satunya adalah sektor pendidikan. Menurut data Organisasi Pendidikan, Keilmuan, dan Kebudayaan PBB (UNESCO, 2020), disebutkan bahwa penutupan sekolah menyebabkan aktivitas belajar setidaknya 290,5 juta siswa di seluruh dunia menjadi terganggu. Hal ini dikhawatirkan akan berdampak pada dunia pendidikan dalam jangka panjang yang dapat mengancam masa depan pelajar di seluruh dunia, termasuk Indonesia. Oleh sebab itu, untuk meredakan kepanikan sosial dalam penyelenggaraan pendidikan, pemerintah Indonesia melakukan pengkajian terkait kurikulum 
darurat COVID-19 untuk memastikan aktivitas pembelajaran tidak terhenti, terutama berjalannya pendidikan dasar, karena pendidikan dasar merupakan pondasi dari semua jenjang pendidikan selanjutnya.

Kurikulum 2013 diterapkan dengan pembelajaran tematik untuk jenjang pendidikan dasar SD/MI yang dilaksanakan dengan menyesuaikan karakteristik pembelajaran dan karakteristik kompetensi. Hal ini dijelaskan dalam Permendikbud No. 22 Tahun 2016 tentang Standar Proses Pendidikan Dasar dan Menengah yang menekankan bahwa pembelajaran SD/MI dilaksanakan melalui pendekatan tematik. Agar proses pembelajaran tematik tersebut dapat tetap berjalan dengan semestinya maka pemerintah mengeluarkan kebijakan dalam rangka memutus penyebaran virus yang diumumkan secara tertulis dalam Surat Edaran No. 4 Tahun 2020 tentang Pelaksanaan Kebijakan Pendidikan dalam Masa Darurat Penyebaran COVID-19 yaitu menghentikan segala kegiatan yang berisikan kerumunan orang (social distancing), dengan peraturan Belajar Dari Rumah (BDR) bagi pelajar dan mahasiswa atau biasa disebut dengan pembelajaran dalam jaringan (daring).

Keberhasilan pembelajaran luring maupun daring bergantung pada kualitas pembelajaran. Terdapat tiga dimensi utama dalam menentukan kualitas pembelajaran, yaitu persiapan pembelajaran atau perencanaan pembelajaran, proses pembelajaran atau pelaksanaan pembelajaran dan evaluasi pembelajaran. Mengacu pada Permendiknas RI No. 41 Tahun 2007 tentang Standar Proses untuk Satuan Pendidikan Dasar dan Menengah, tahap awal dalam pembelajaran yaitu perencanaan pembelajaran yang direalisasikan dalam bentuk kegiatan penyusunan Rencana Pelaksanaan Pembelajaran (RPP) oleh guru. Tahap pembelajaran selanjutnya yaitu implementasi RPP yang telah disusun secara sistematis dalam proses pelaksanaan pembelajaran di kelas. Cara guru dalam menerapkan rancangan kegiatan pembelajaran sangat mempengaruhi keberhasilan tujuan pembelajaran, terutama pada pembelajaran tematik. Kegiatan dalam pembelajaran tematik dilaksanakan dengan mengaitkan beberapa mata pelajaran berdasarkan suatu tema tertentu sehingga diharapkan dapat memberikan pengalaman pembelajaran bermakna pada peserta didik. Sedangkan evaluasi pembelajaran berfungsi untuk mengadakan perbaikan dan pengayaan bagi peserta didik yang biasanya dapat dilihat melalui hasil belajar.

Pembelajaran tematik merupakan salah satu bentuk dari pembelajaran terpadu, yaitu webbed model (model terjala). Menurut Joni, T.R (dalam Trianto, 2010) pembelajaran terpadu merupakan sistem pembelajaran yang mendorong siswa baik secara individual maupun kelompok untuk aktif mencari, menggali, dan menemukan konsep serta prinsip keilmuan secara holistik, bermakna, dan autentik. Beberapa komponen penting yang mencerminkan nuansa pembelajaran tematik diantaranya: a) penguasaan materi pelajaran; b) pendekatan/strategi pembelajaran, c) pemanfaatan media pembelajaran/sumber belajar; d) pembelajaran yang memicu dan memelihara keterlibatan siswa; e) kemampuan khusus dalam pembelajaran bidang studi; f) penilaian proses dan hasil belajar; g) penggunaan bahasa; serta h) refleksi dan rangkuman. Pada pembelajaran tematik menekankan pada pola pengorganisasian materi yang terintegrasi dipadukan oleh suatu tema tertentu. Pengambilan tema dilakukan sesuai dengan kompetensi dasar dan topik-topik (standar isi) dari mata pelajaran, namun dikembangkan dari luar mata pelajaran (Kurniawan, 2014).

Terdapat beberapa tahapan dalam mengimplementasikan pembelajaran tematik di SD. Menurut Ahmadi dan Amri (2014), menyebutkan beberapa tahapan dari implementasi 
pembelajaran tematik di SD antara lain: 1) Pada tahap perencanaan, guru melakukan beberapa bentuk rancangan untuk mempersiapkan pembelajaran seperti pemetaan KD, penentuan tema, analisis indikator penetapan jaringan tema, penyusunan silabus, dan penyusunan RPP. Pijakan awal dalam kegiatan ini adalah karakteristik mata pelajaran. Kemudian dalam RPP yang digunakan terdapat beberapa komponen seperti identitas, perumusan tujuan pembelajaran, pengorganisasian materi ajar, pemilihan metode, sumber dan atau media pembelajaran, serta langkah-langkah pembelajaran. Pada penelitian ini, analisis dilakukan terhadap RPP tematik yang digunakan selama masa pembelajaran daring. 2) Pada tahap pelaksanaan, kegiatan pembelajaran dibagi menjadi tiga tahapan yaitu pendahuluan atau pembuka, inti, dan penutup. Pelaksanaan pembelajaran yang sesuai dengan prinsip dan karakteristik kompetensi pembelajaran tematik menghasilkan outcome dalam bentuk hasil belajar siswa maupun manfaat lainnya seperti: a) penghematan waktu dan tenaga yang disebabkan oleh penggabungan antara beberapa kompetensi dasar, indikator, dan muatan sehingga tumpang tindih materi berkurang; b) peran materi pembelajaran sebagai sarana untuk membantu siswa dalam melihat hubungan-hubungan yang bermakna; c) siswa memperoleh pengertian mengenai proses dan materi yang tidak terpecah-pecah; dan d) perpaduan antar muatan meningkatkan penguasaan konsep, hal ini sesuai dengan tahap perkembangan siswa Sekolah Dasar yaitu melihat segala hal sebagai keseluruhan. 3) Pada tahap evaluasi, penilaian dilakukan sebagai petunjuk dalam mengetahui hasil belajar siswa, guru perlu melaksanakan evaluasi pembelajaran. Evaluasi dilakukan dari segi proses dan hasil. Alat penilaian yang digunakan berupa tes dan non tes yang di dalamnya terdiri dari tes tertulis, tes lisan, tes perbuatan, catatan perkembangan siswa, dan portofolio. Penilaian pada pembelajaran tematik di SD dikembalikan pada kompetensi dari setiap muatan serta dipisahkan sesuai aspek pengetahuan, keterampilan, dan sikap. Sedangkan evaluasi pembelajaran tematik dalam pembelajaran daring dapat dilakukan dalam setiap kegiatan antara lain dengan memberikan kesempatan kepada siswa untuk mengevaluasi perolehan belajar berdasarkan target pencapaian pada tujuan pembelajaran.

Sekolah-sekolah yang telah menerapkan kurikulum 2013 tentunya sudah familiar dengan sistem pembelajaran tematik, salah satunya SDN Cemorokandang 4 Malang. Sebagai bahan pertimbangan studi awal, peneliti telah melakukan observasi di salah satu SD yang termasuk dalam Gugus 3 Kedungkandang Kota Malang. Berdasarkan pengalaman peneliti selama melaksanakan kegiatan Kajian dan Praktik Lapangan (KPL II) di SDN Cemorokandang 4 pada 10 Agustus 2020 - 21 Oktober 2020, peneliti mengidentifikasi beberapa permasalahan yang sedang terjadi. Selama masa pandemi COVID-19, setiap sekolah tentunya berinovasi dalam melakukan penyesuaian terhadap model-model pembelajaran daring. Dari hasil observasi kelas peneliti menemui ketidaksesuaian antara RPP yang ditunjukkan dengan proses pembelajaran dalam kelas, serta pembelajaran yang tidak lagi bernuansa tematik. Guru kelas menuturkan bahwa hal ini disebabkan oleh ketidaksiapan sekolah dengan prosedur baru pembelajaran daring, sehingga sekolah terpaksa mengeluarkan kebijakan sendiri. Dari hasil wawancara yang dilakukan dengan guru pamong sekaligus wali kelas I, latar belakang ekonomi siswa SDN Cemorokandang 4 mayoritas berasal dari keluarga dengan tingkat ekonomi menengah ke bawah, tidak semua wali murid mempunyai HP Android yang dapat menunjang aktivitas pembelajaran daring, sehingga pelaksanaan Pembelajaran Jarak Jauh (PJJ) belum terlaksana dengan maksimal, bahkan proses pembelajaran tidak berlangsung sesuai dengan RPP daring yang telah disusun. 
Pembelajaran tematik pada SDN Cemorokandang 4 berjalan secara tidak terstruktur, yaitu menyesuaikan dengan situasi dan kondisi. Sistem pembelajaran dilakukan dengan tatap muka satu kali dalam satu pekan, dan pada kegiatan tatap muka pembahasan materi hanya dilakukan sesuai dengan urgensi mata pelajaran. Sedangkan nuansa tematik hanya didapatkan dalam pembuatan modul BDR yang diberikan kepada siswa setiap minggunya. Sehingga tujuan kajian artikel ini adalah untuk mengetahui lebih lanjut mengenai kesesuaian penerapan pembelajaran tematik pada tiga dimensi pembelajaran yaitu perencanaan, pelaksanaan, dan evaluasi dalam pembelajaran daring selama masa pandemi COVID-19, serta faktor-faktor penyebab terjadinya permasalahan tersebut.

\section{Metode}

Penelitian ini menggunakan pendekatan kuantitatif dengan hasil pengolahan data berupa angka. Sugiyono (2018) mendefinisikan penelitian kuantitatif sebagai pendekatan yang digunakan untuk meneliti populasi atau sampel tertentu, dengan menggunakan instrumen penelitian dalam pengumpulan datanya, serta analisis data yang bersifat kuantitatif/statistik untuk menguji hipotesis yang telah ditetapkan.

Dalam penelitian ini, peneliti menggunakan jenis penelitian deskriptif kuantitatif. Penelitian deskriptif dilakukan dengan menjelaskan atau menggambarkan variabel yang sedang terjadi. Data yang diperoleh dianalisis menggunakan statistik deskriptif dalam bentuk tabel distribusi frekuensi untuk memaparkan data, rumus persentase, dan pemaparan data menggunakan kata atau kalimat (Arikunto, 2010).

Metode yang digunakan adalah metode ex-post facto. Menurut Kerlinger (1973), metode penelitian yang juga dikenal dengan penelitian kausal komparatif ini merupakan penyelidikan empiris yang sistematis dimana eksistensi dari variabel yang digunakan telah terjadi sehingga peneliti tidak mengendalikan variabel, atau karena pada dasarnya variabel tersebut tidak dapat dimanipulasi. Sehingga kesimpulan terbentuk berdasarkan perbedaan yang mengiringi variabel bebas dan variabel terikat tanpa adanya campur tangan peneliti.

Populasi dalam penelitian ini adalah seluruh guru kelas dan siswa kelas IV SD Gugus 3 Kedungkandang Kota Malang, diantaranya: 1) Guru dan Siswa Kelas IV SDN Cemorokandang 1 Kota Malang, 2) Guru dan Siswa Kelas IV SDN Cemorokandang 2 Kota Malang, 3) Guru dan Siswa Kelas IV SDN Cemorokandang 3 Kota Malang, 4) Guru dan Siswa Kelas IV SDN Cemorokandang 4 Kota Malang, dan 5) Guru dan Siswa Kelas IV MI Cemorokandang Kota Malang. Dengan menggunakan teknik sampling yang dilakukan dengan cara memberikan peluang yang sama bagi setiap anggota populasi untuk dipilih menjadi anggota sampel, yaitu dengan menggunakan Purposive Sampling. Pemilihan teknik tersebut didasarkan pada kriteria tertentu yaitu peneliti hanya mengambil sampel dari Sekolah Dasar (SD), sehingga menggugurkan Madrasah Ibtidaiyah (MI). Dari keseluruhan populasi guru kelas IV diambil sampel 4 guru SDN dan 90 siswa dengan keterangan sebagai berikut.

Tabel 1. Sampel Penelitian

\begin{tabular}{lllccc}
\hline No & Gugus & SD/MI & Guru Kelas IV & Siswa Kelas IV & Ket \\
\hline 1. & Gugus 3 & SDN Cemorokandang 1 & 1 & 25 & - \\
& & SDN Cemorokandang 2 & 1 & 28 & - \\
& & SDN Cemorokandang 3 & 1 & 9 & - \\
& SDN Cemorokandang 4 & 1 & 28 & - \\
\hline Jumlah & & 4 & 90 & \\
\hline
\end{tabular}


Data diperoleh dengan menggunakan teknik pengumpulan data secara kuantitatif. Teknik pengumpulan data yang digunakan dalam penelitian ini antara lain: 1) Data primer, yaitu data utama yang diperoleh dengan menggunakan teknik observasi RPP, angket penilaian pelaksanaan pembelajaran, dan dokumentasi nilai siswa. 2) Data sekunder, yaitu digunakan sebagai pendukung analisis data yang diperoleh dengan menggunakan teknik wawancara.

Setelah selesai mengumpulkan data, maka tahap selanjutnya adalah analisis data. Dalam penelitian kuantitatif deskriptif menggunakan metode analisis statistik deskriptif yaitu dengan cara mendeskripsikan hasil data yang diperoleh. Sebagai data pendukung yang digunakan untuk mendeskripsikan penerapan evaluasi pembelajaran, penulis melakukan tabulasi persilangan antara hasil belajar siswa dengan perencanaan dan pelaksanaan pembelajaran yaitu dengan menggunakan analisis Chi Square. Data hasil belajar akan diambil dari nilai posttest atau raport yang berkaitan dengan subtema yang ditentukan. Rumus Chi Square yang digunakan yaitu sebagai berikut:

$X^{2}=\sum\left[\frac{(f o-f e)^{2}}{f e}\right]$

Keterangan :

$\mathrm{X}^{2}=$ nilai chi-square

$\mathrm{fo}=$ frekuensi yang diperoleh (obtained frequency)

$\mathrm{fe}=$ frekuensi yang diharapkan (expected frequency)

Untuk memudahkan pengujian data pada penelitian maka akan digunakan program SPSS 16.0 for windows.

\section{Hasil dan Pembahasan}

Hasil pengumpulan data yang didapatkan kemudian diolah secara kuantitatif sehingga menghasilkan paparan kualifikasi sub variabel yang disajikan pada tabel berikut.

Tabel 2. Kualifikasi Implementasi Pembelajaran Tematik dalam Pembelajaran Daring Kelas IV SD Gugus 3 Kedungkandang Kota Malang

\begin{tabular}{lcccc}
\hline \multicolumn{1}{c}{ Sub Variabel } & $\begin{array}{c}\text { Skor yang } \\
\text { Diperoleh }\end{array}$ & $\begin{array}{c}\text { Skor } \\
\text { Maksimal }\end{array}$ & $\begin{array}{c}\text { Persentase } \\
\text { (\%) }\end{array}$ & Kualifikasi \\
\hline $\begin{array}{l}\text { Perencanaan Pembelajaran } \\
\text { Tematik }\end{array}$ & 703 & 880 & 79,89 & Sedang \\
$\begin{array}{l}\text { Pelaksanaan Pembelajaran } \\
\text { Tematik }\end{array}$ & 860 & 940 & 91,49 & Tinggi \\
$\begin{array}{l}\text { Evaluasi Pembelajaran } \\
\text { Tematik }\end{array}$ & 19.995 & 27.000 & 74,06 & Sedang \\
\hline Total & 21.558 & 28.820 & 74,80 & Sedang \\
\hline
\end{tabular}

Dari sajian data pada tabel 2 menggambarkan bahwa implementasi pembelajaran tematik di Gugus 3 Kedungkandang berkualifikasi sedang. Rincian persentase sub variabel diperjelas dalam histogram berikut. 


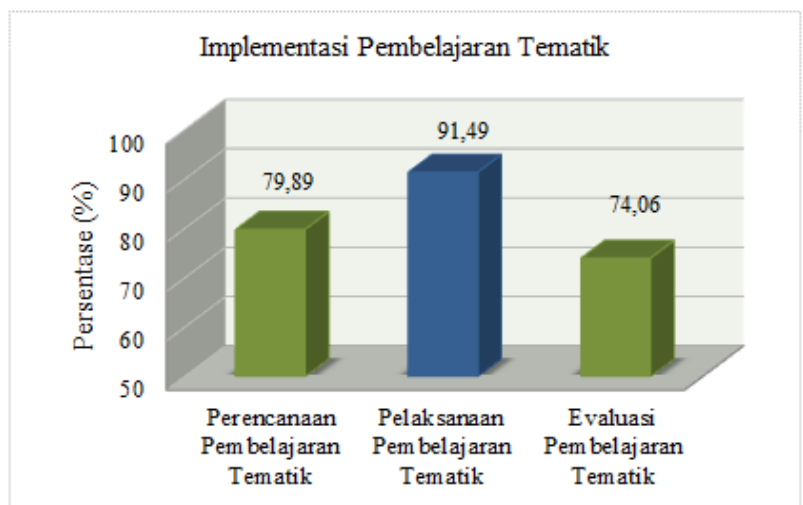

Gambar 1. Persentase Implementasi Pembelajaran Tematik dalam Pembelajaran Daring Kelas IV SD Gugus 3 Kedungkandang Kota Malang

\subsection{Implementasi Perencanaan Pembelajaran}

Pada kurikulum 2013, penentuan jaringan tema tidak dilakukan oleh guru, melainkan sudah ditetapkan oleh pemerintah. Sehingga guru merancang kegiatan perencanaan pembelajaran dimulai dari penetapan indikator yang dibuat berdasarkan Kompetensi Dasar (KD). Kemudian dilengkapi dengan komponen-komponen mendasar lainnya meliputi muatan, kelas, semester, dan waktu/durasi pertemuan yang dialokasikan (Prabowo, 2000 dalam Trianto, 2011). Berdasarkan hasil penelitian ditemukan beberapa informasi yang dijabarkan pada setiap indikator sub variabel perencanaan pembelajaran tematik yaitu: 1) Kelengkapan komponen RPP, pada RPP yang dibuat oleh keempat guru tersebut sudah memenuhi kriteria komponen identitas RPP, meskipun tidak mencantumkan detail muatan yang akan digabungkan, namun hal ini digantikan dengan menuliskan rincian tema dan subtema secara lengkap; 2) Perumusan tujuan pembelajaran, seluruh RPP dibuat dengan tanpa perumusan indikator, namun digabungkan pada bagian tujuan pembelajaran. Hasil analisis pada tujuan pembelajaran berdasarkan indikator ABCD yaitu A (Audience), B (Behavior), C (Condition), dan D (Degree) menunjukkan bahwa setiap RPP sudah mencantumkan Audience yaitu dengan menyebutkan "siswa" sebagai subjek dan objek dalam pembelajaran, Behavior dengan mencantumkan Kata Kerja Operasional (KKO) yang sesuai dengan Kompetensi Inti (KI), dan Condition dengan memuat aktivitas yang akan dilakukan. Namun tidak ditemukan Degree yang seharusnya dicantumkan dengan merinci target pencapaian berupa angka. Hal ini tentunya bertentangan dengan prinsip kegiatan pembelajaran berbasis kurikulum tematik yang seharusnya dilakukan secara serius, terarah, dan terukur; 3) Penyajian dan pengorganisasian materi ajar, pada indikator ini berkualifikasi rendah karena guru SDN Cemorokandang 2 tidak mencantumkan materi ajar pada lampiran RPP, sehingga peneliti tidak dapat mengamati dan menindaklanjuti sajian bermuatan fakta, konsep, prinsip, dan prosedur pada materi ajar; 4) Pemilihan metode dan sumber/media pembelajaran, beberapa guru sudah mencantumkan pendekatan dan metode yang digunakan, namun belum mencantumkan sumber/media pembelajaran. Akan tetapi sumber/media pembelajaran dapat dilihat jelas pada penjabaran indikator ke; 5) perincian langkah-langkah pembelajaran, sehingga hal ini dapat mempermudah dalam menyesuaikan sumber/media pembelajaran yang akan digunakan; dan pada indikator; 6) Penyusunan instrumen evaluasi berkualifikasi rendah, karena tidak terdapat instrumen soal pada bagian lampiran, melainkan hanya tercantum kriteria-kriteria penilaian yang dikembalikan pada aspek pengetahuan, keterampilan, dan sikap. 
Berdasarkan hasil observasi yang dilakukan dengan menganalisis 24 sampel RPP Tema 5 Subtema 1 Pembelajaran 1-6 dari SDN Cemorokandang 1, SDN Cemorokandang 2, SDN Cemorokandang 3, dan SDN Cemorokandang 4 menunjukkan bahwa secara umum RPP berkualitas cukup baik dengan kualifikasi sedang $(79,89 \%)$.

\subsection{Implementasi Pelaksanaan Pembelajaran}

Dalam pelaksanaan pembelajaran tematik selama masa pandemi, masing-masing sekolah mempunyai cara tersendiri dalam menyiasati jalannya pembelajaran. Berdasarkan hasil penelitian ditemukan beberapa informasi yang dijabarkan pada setiap indikator sub variabel pelaksanaan pembelajaran tematik yaitu Kegiatan Pendahuluan Pembelajaran, penerapan pendahuluan pembelajaran di SDN Cemorokandang 1 didahului dengan pertanyaan yang berkaitan dengan materi ajar untuk menstimulasi kemampuan berpikir anak. Hal yang sama juga diterapkan di SDN Cemorokandang 3, meskipun pelaksanaan pembelajaran hanya dilakukan satu kali dalam sepekan, guru tetap rutin menyampaikan kompetensi yang akan dicapai bahkan disertai dengan penyampaian rencana kegiatan dalam sepekan kedepan. Sedangkan guru SDN Cemorokandang 2 dan SDN Cemorokandang 4 menuturkan bahwa pada pembelajaran selama masa pandemi sesekali melewatkan kegiatan apersepsi pada pendahuluan pembelajaran untuk efektifitas dan efisiensi waktu, Sedangkan apersepsi merupakan bagian penting sebelum memulai pembelajaran.

Indikator selanjutnya yaitu Kegiatan Inti Pembelajaran, terbagi menjadi beberapa sub indikator yang terdiri atas: (a) Karakteristik pokok pembelajaran tematik. Kesulitan utama dalam mempertahankan karakteristik pembelajaran tematik selama masa pembelajaran daring ialah dalam meminimalisir verbalisme. Kurangnya intensitas pertemuan mengakibatkan sering terjadinya miskonsepsi dalam pembelajaran, sehingga metode ceramah lebih sering dilakukan dalam rangka upaya pencapaian target pembelajaran; (b) Penguasaan materi pelajaran. Guru SDN Cemorokandang 4 mengungkapkan bahwa pemilihan metode penugasan mengakibatkan sulitnya mengaitkan materi dengan pengetahuan lain yang relevan. Sedangkan keberhasilan penciptaan suasana pembelajaran tematik bergantung pada metode dan media pembelajaran yang digunakan. Sehingga guru lebih mementingkan pada pencapaian materi pokok; (c) Pendekatan/strategi pembelajaran. Meskipun terkendala media dan ruang ajar, namun guru tetap melaksanakan pembelajaran daring yang bersifat kontekstual dan sesuai dengan target pencapaian kompetensi, contohnya dengan memanfaatkan benda-benda yang mudah ditemui di lingkungan sekitar siswa selama masa BDR. Pendapat lain dilontarkan oleh guru kelas IV SDN Cemorokandang 4 yang beranggapan bahwa untuk mempertahankan konsistensi dalam melaksanakan kegiatan pembelajaran secara runtut sesuai sintaks yang sudah ditentukan bukanlah hal yang mudah untuk dilakukan selama masa pembelajaran daring, mengingat durasi waktu yang lebih singkat tidak sebanding dengan tuntutan target pembelajaran; (d) Pemanfaatan media pembelajaran/sumber belajar. Media pembelajaran sudah disediakan oleh pihak sekolah. Dalam situasi pandemi, pertemuan tatap muka tetap dimanfaatkan oleh guru untuk melakukan demonstrasi media pembelajaran. Namun hal ini tidak dapat dilakukan semaksimal saat pembelajaran luring sebelumnya, karena intensitas pertemuan yang tidak memungkinkan untuk menjalankan pembelajaran secara normal; (e) Pembelajaran yang memicu dan memelihara keterlibatan siswa. Pada pembelajaran daring via grup WhatsApp belum memungkinkan adanya interaksi antara siswa dengan siswa. Oleh karena itu, guru SDN Cemorokandang 2 meniadakan tugas kelompok pada setiap pembelajaran dan diganti dengan melibatkan siswa secara aktif dalam interaksi guru dengan siswa. Sehingga 
hasil belajar yang diperoleh siswa merupakan hasil belajar individu; (f) Kemampuan khusus dalam pembelajaran bidang studi. Kemampuan guru dalam bidang studi diterapkan dalam berbagai hal, salah satunya dengan menunjukkan penggunaan pengalaman langsung sesuai konteks lingkungan, contohnya mempraktekkan uji coba pembiasan cahaya pada muatan IPA. Yang membedakan adalah penjelasan materi yang disertai dengan demonstrasi dilakukan secara daring, melalui rekaman video yang dikirim ke grup WhatsApp maupun demonstrasi langsung via Zoom. Dalam hal ini setiap guru mempunyai kemampuan yang berbeda di bidangnya masing-masing; (g) Penilaian proses dan hasil belajar. Guru kelas tetap memantau kemajuan belajar siswa dengan membuat catatan anekdot. Sedangkan di SDN Cemorokandang 4, penilaian proses dan hasil tetap dilakukan namun terkadang pre-test atau penilaian awal pembelajaran ditiadakan untuk efisiensi waktu; dan (h) Penggunaan bahasa. Guru kelas 4 SDN Cemorokandang 4 menuturkan bahwa setiap guru memiliki kemampuan komunikasi yang berbeda-beda. Sehingga terkadang ketidaktepatan dalam pemilihan diksi pada saat menjelaskan materi sangat berpengaruh pada pemahaman siswa. Pembelajaran daring yang dilakukan melalui WhatsApp pun terkadang mengalami masalah yang sama, ketika bahasa lisan dan tulisan terkesan berbeda, hal ini menyebabkan sering terjadinya miskonsepsi pada siswa baik dalam pemaparan materi maupun penugasan.

Kemudian indikator terakhir yaitu Kegiatan Penutup Pembelajaran. Ketidakstabilan sistem pembelajaran di masa pandemi menyebabkan ketidakteraturan dalam pelaksanaan pembelajaran. Hal penting yang sering dilewatkan guru yaitu memaksimalkan penutup pembelajaran. Kegiatan pada tahap akhir ini cukup kompleks namun tidak memakan waktu yang lama. Oleh sebab itu, guru sering mengakhiri pembelajaran lebih cepat dari waktunya jika sedang dalam keadaan terburu-buru.

Dari hasil wawancara guru, kendala utama yang dihadapi oleh guru adalah waktu dan media ajar. Perpindahan ruang ajar dari offline menjadi online mempengaruhi banyak hal, sehingga guru dituntut untuk memaksimalkan pembelajaran dalam kondisi apapun, bahkan dengan keterbatasan media ajar. Rusman (2012) mengungkapkan bahwa dalam kegiatan pembelajaran tematik perlu mengoptimalisasi penggunaan media pembelajaran yang bervariasi sehingga kegiatan pembelajaran akan berlangsung secara efektif. Sementara pada aspek lain, semua guru telah menerapkan pelaksanaan pembelajaran tematik dengan baik. Hal ini dibuktikan dengan perolehan skor berkualifikasi tinggi (91,49\%).

\subsection{Implementasi Evaluasi Pembelajaran}

Pada tahap penilaian pembelajaran, semua guru kelas IV dari keempat sekolah tersebut tetap mengadakan penilaian proses dan hasil. Berdasarkan informasi yang didapatkan dari hasil wawancara kepada masing-masing guru, penilaian proses diambil dari penilaian kinerja seperti produk dan karya, portofolio tertulis, serta penilaian sikap saat kegiatan pembelajaran daring berlangsung. Sedangkan penilaian hasil diperoleh dari penugasan yang dikumpulkan secara offline sesuai dengan jadwal masing-masing kelas. Hal ini didukung oleh pendapat Trianto (2011) bahwa penilaian proses belajar adalah upaya pemberian nilai terhadap kegiatan pembelajaran yang dilakukan oleh guru dan peserta didik, sedangkan penilaian hasil belajar adalah proses pemberian nilai terhadap hasil-hasil belajar yang dicapai oleh peserta didik, dengan menggunakan kriteria-kriteria tertentu. 
Indikator penilaian yang membedakan terdapat pada kriteria-kriteria yang mencerminkan karakteristik pembelajaran daring. Diantaranya yaitu penilaian ekspresi, partisipasi dalam penyampaian ide dan gagasan, komunikasi verbal dan non verbal dalam bentuk kontak mata, bahasa tubuh, dan suara. Hal-hal tersebut menjadi perhatian utama dalam pelaksanaan pembelajaran daring.

Rata-rata keseluruhan nilai keterampilan dari keempat sekolah tersebut yaitu 77,78 dengan kategori tinggi. Artinya, implementasi evaluasi pembelajaran pada aspek keterampilan berjalan dengan baik. Pada pembelajaran tematik, nilai keterampilan merupakan aspek penting yang menggambarkan keterlibatan siswa dalam pembelajaran. Dari hasil penelitian ditemui bahwa selama masa pembelajaran daring setiap guru tetap memberikan penugasan yang bersifat kinerja atau produk. Selain itu, nilai keterampilan juga didapatkan dari partisipasi siswa selama pembelajaran daring berlangsung. Rata-rata keseluruhan nilai sikap dari keempat sekolah tersebut yaitu 83,94 dengan kategori tinggi. Artinya, implementasi evaluasi pembelajaran pada aspek sikap berjalan dengan baik. Pemerolehan nilai sikap didapatkan dengan cara yang berbeda-beda. Sebagian nilai dipertimbangkan dari hasil wawancara orang tua siswa, pengisian tabel laporan penilaian spiritual, dan kegiatan-kegiatan lain yang menggambarkan perkembangan sikap dan perilaku siswa selama masa pembelajaran daring. Guru kelas 4 SDN Cemorokandang 2 mengungkapkan ketidakmungkinan untuk melanjutkan rutinitas penilaian sikap, sehingga guru mengambil nilai dengan membuat form pelaporan penilaian aspek spiritual dan aspek sosial sebagai pengganti penilaian sikap. Berdasarkan hasil penelitian secara umum keempat sekolah tersebut dapat mengimplementasikan evaluasi pembelajaran tematik dengan cukup baik. Hal ini dibuktikan dengan perolehan skor berkualifikasi sedang $(74,80 \%)$.

\subsection{Hubungan Antara Hasil Belajar Siswa dengan Perencanaan Pembelajaran}

Perhitungan analisis uji korelasi menggunakan tabulasi persilangan Chi Square menunjukkan nilai signifikansi 0,042<0,05 maka $\mathrm{Ha}_{1}$ diterima. Berdasarkan perhitungan tersebut menunjukkan adanya hubungan antara kualitas perencanaan pembelajaran dengan hasil belajar siswa. Artinya, ketika perencanaan pembelajaran yang dibuat oleh guru berkualitas tinggi akan mempengaruhi keberhasilan siswa dalam pembelajaran yaitu dilihat dari prestasi belajar siswa, dan sebaliknya. Menurut PP nomor 19 tahun 2005 yang berkaitan dengan Standar Proses mengisyaratkan bahwa guru diharapkan dapat mengembangkan perencanaan pembelajaran dengan baik.

Hal tersebut dipertegas melalui Peraturan Menteri Pendidikan Nasional (Permendiknas) nomor 41 Tahun 2007 tentang Standar Proses, yang antara lain mengatur perencanaan pembelajaran yang mensyaratkan bagi pendidik pada satuan pendidikan untuk mengembangkan RPP, khususnya pada jenjang pendidikan dasar dan menengah jalur formal. Dalam Standar Proses dijelaskan bahwa RPP dijabarkan dari silabus untuk mengarahkan kegiatan belajar peserta didik dalam upaya mencapai KD. Penyusunan RPP harus dirancang dengan berpusat pada peserta didik untuk mendorong motivasi, minat, kreativitas, inisiatif, inspirasi, kemandirian, dan semangat belajar. Untuk itu, setiap guru pada satuan pendidikan berkewajiban menyusun RPP secara lengkap dan sistematis agar pembelajaran berlangsung secara interaktif, inspiratif, menyenangkan, menantang, memotivasi peserta didik untuk berpartisipasi aktif, serta memberikan ruang yang cukup bagi prakarsa, kreativitas, dan 
kemandirian sesuai dengan bakat, minat, dan perkembangan fisik serta psikologis peserta didik.

Hasil analisis pada hipotesis pertama menyatakan bahwa $\mathrm{Ha}_{1}$ diterima dan $\mathrm{Ho}$ ditolak. Dapat disimpulkan bahwa terdapat hubungan antara hasil belajar siswa dengan kualitas perencanaan pembelajaran. Artinya, kemampuan guru dalam menyusun perencanaan pembelajaran mempengaruhi keberhasilan siswa dalam mencapai target pembelajaran baik dari segi proses maupun hasil.

\subsection{Hubungan Antara Hasil Belajar Siswa dengan Pelaksanaan Pembelajaran}

Perhitungan analisis uji korelasi menggunakan tabulasi persilangan Chi Square menunjukkan nilai signifikansi 0,028 $<0,05$ maka $\mathrm{Ha}$ diterima. Berdasarkan perhitungan tersebut menunjukkan adanya hubungan antara hasil belajar siswa dengan kualitas pelaksanaan pembelajaran. Artinya, ketika guru memiliki kemampuan dalam menerapkan proses pembelajaran dengan baik, hal ini berkemungkinan besar akan berpengaruh pada hasil belajar siswa, begitu pula sebaliknya. Hal tersebut diperkuat juga oleh penelitian Wijayanti (2009) bahwa prestasi belajar siswa yang diperoleh tidak terlepas dari peran guru dalam proses pembelajaran. Jika guru mampu melaksanakan pembelajaran dengan tepat maka siswa pun akan termotivasi untuk belajar sehingga memperoleh hasil belajar yang maksimal.

Guru dituntut untuk mampu menerapkan pelaksanaan pembelajaran dengan baik demi tercapainya tujuan pembelajaran. Menurut Mulyasa (2007) guru juga menentukan keberhasilan peserta didik, terutama dalam kaitannya dengan proses belajar mengajar. Guru merupakan komponen yang paling berpengaruh terhadap terciptanya proses dan hasil pendidikan yang berkualitas. Oleh karena itu, upaya perbaikan apapun yang dilakukan untuk meningkatkan kualitas pendidikan tidak akan memberikan perubahan yang signifikan tanpa didukung oleh guru yang profesional dan berkualitas. Dengan kata lain, perbaikan kualitas pendidikan harus berpangkal dari kinerja guru dan berujung pada guru pula.

Hasil analisis pada hipotesis kedua menyatakan bahwa $\mathrm{Ha}_{2}$ diterima dan $\mathrm{Ho}_{2}$ ditolak. Dapat disimpulkan bahwa terdapat hubungan antara hasil belajar siswa dengan kualitas pelaksanaan pembelajaran. Artinya, keberhasilan siswa dalam mencapai target pencapaian pembelajaran dipengaruhi oleh kemampuan guru dalam menerapkan pelaksanaan pembelajaran.

\subsection{Hubungan Antara Hasil Belajar Siswa dengan Perencanaan dan Pelaksanaan Pembelajaran}

Perhitungan analisis uji korelasi menggunakan tabulasi persilangan Chi Square menunjukkan nilai signifikansi 0,045 $<0,05$ maka $\mathrm{Ha}_{3}$ diterima. Berdasarkan perhitungan tersebut menunjukkan adanya hubungan antara hasil belajar siswa dengan kualitas perencanaan dan pelaksanaan pembelajaran. Artinya, antara perencanaan dan pelaksanaan pembelajaran dengan hasil belajar siswa mempunyai hubungan yang signifikan. Karena semakin baik perencanaan dan pelaksanaan pembelajaran guru maka hasil belajar siswa akan semakin baik pula. Perencanaan guru diukur dari pembuatan RPP dan pelaksanaan pembelajaran diukur dari proses atau penerapan pembelajaran tematik di kelas. Berdasarkan hasil penelitian, kualitas perencanaan dan pelaksanaan pembelajaran guru kelas IV dari keempat sekolah tersebut tergolong baik sehingga hasil belajar siswa juga berkategori baik. 
Pelaksanaan pembelajaran merupakan implementasi dari perencanaan yaitu RPP. Dalam pelaksanaan pembelajaran guru dituntut untuk mampu mengkondisikan kelas sebaik mungkin sehingga tercipta suasana pembelajaran yang nyaman dan menyenangkan. Jika pelaksanaan pembelajaran berjalan dengan baik dan sesuai dengan perencanaan maka akan memupuk kerja sama yang harmonis antara siswa dan guru. Hamalik (1994) mengemukakan bahwa siswa memberikan respon dan berperilaku baik jika guru bersifat menunjang dan membantu selama berlangsungnya pembelajaran. Motivasi siswa dipengaruhi secara positif oleh guru yang bersemangat dan antusias terhadap isi/materi yang diajarkan. Guru juga perlu memberikan kesempatan berpendapat serta umpan balik yang positif sepanjang berlangsungnya kegiatan belajar mengajar. Untuk itu, guru perlu menciptakan suasana lingkungan kelas yang menyenangkan dan menunjang pembelajaran sehingga membangkitkan motivasi siswa untuk mencapai hasil belajar yang positif.

Dalam pembelajaran daring selama masa pandemi, guru-guru beranggapan bahwa pembelajaran tematik tidak bisa dipaksa untuk terlaksana dengan maksimal. Namun setiap guru tetap mengusahakan dengan caranya masing-masing untuk mencapai keberhasilan pembelajaran, yaitu dengan memperhatikan aspek perencanaan, pelaksanaan, dan evaluasi pembelajaran. Oleh sebab itu, dapat disimpulkan bahwa antara perencanaan dan pelaksanaan pembelajaran guru dengan hasil belajar siswa mempunyai hubungan yang signifikan. Semakin baik perencanaan dan pelaksanaan pembelajaran guru maka semakin baik pula hasil belajar siswa, karena perencanaan dan pelaksanaan pembelajaran guru yang baik dan berkualitas akan membuat siswa lebih tertarik dan termotivasi terhadap pelajaran sehingga hasil belajar siswa juga akan baik.

Hasil analisis pada hipotesis ketiga menyatakan bahwa $\mathrm{H}_{3}$ diterima dan $\mathrm{Ho}_{3}$ ditolak. Dapat disimpulkan bahwa terdapat hubungan antara hasil belajar siswa dengan kualitas perencanaan dan pelaksanaan pembelajaran. Artinya, hasil belajar siswa sebagian besar dipengaruhi oleh perencanaan dan pelaksanaan pembelajaran.

\section{Simpulan}

Implementasi pembelajaran tematik dalam pembelajaran daring Kelas IV SD Gugus 3 Kedungkandang pada tahap perencanaan pembelajaran, seluruh RPP sudah menggunakan model RPP tematik, namun sebagian guru masih menggunakan RPP luring. RPP dari guru kelas IV SD Gugus 3 Kedungkandang berkualitas cukup baik dengan kualifikasi sedang (79,89\%). Pada tahap pelaksanaan pembelajaran, setiap sekolah melakukan pembelajaran dengan cara yang berbeda yaitu luring, daring, dan semi-daring. Penerapan pelaksanaan pembelajaran daring oleh guru kelas IV SD Gugus 3 Kedungkandang berkualitas baik dengan kualifikasi tinggi (91,49\%). Pada tahap evaluasi pembelajaran, seluruh RPP sudah menggunakan model RPP tematik dengan mengembalikan nilai pada aspek pengetahuan, keterampilan, dan sikap. Penerapan evaluasi pembelajaran daring oleh guru kelas IV SD Gugus 3 Kedungkandang berkualitas cukup baik dengan dengan kualifikasi sedang $(74,80 \%)$. Terdapat hubungan yang positif antara hasil belajar siswa dengan kualitas perencanaan pembelajaran. Dengan hasil analisis uji korelasi menggunakan Chi Square menunjukkan nilai signifikansi 0,042<0,05. Terdapat hubungan yang positif antara hasil belajar siswa dengan kualitas pelaksanaan pembelajaran. Dengan perhitungan analisis uji korelasi menggunakan Chi Square menunjukkan nilai signifikansi 0,028 $<0,05$. Terdapat hubungan yang positif antara hasil belajar siswa dengan kualitas perencanaan dan pelaksanaan pembelajaran. Dengan 
perhitungan analisis uji korelasi menggunakan Chi Square menunjukkan nilai signifikansi $0,045<0,05$.

\section{Daftar Rujukan}

Ahmadi \& Amri S. (2014). Pengembangan Bahan Ajar dan Model Pembelajaran Tematik Integratif. Jakarta: PT Prestasi Pustakaraya.

Arikunto, S. (2010). Prosedur Penelitian Suatu Pendekatan Praktik. Jakarta: Rineka Cipta.

Hamalik, U. (1994). Media Pendidikan. Bandung: Citra Aditya Bakti

Kerlinger, F. N. (1973). Founding of Behavior Research, Holt. Rinchart and Winston Inc. New York.

Kuniawan, D. (2014). Pembelajaran Terpadu Tematik (Teori, Praktik, dan Penilaian). Bandung: Alfabeta.

Mulyasa. (2007). Standar Kompetensi dan Sertifikasi Guru. Bandung: PT. Remaja Rosdakarya

Permendikbud. (2016). Permendikbud RI No. 22 Tahun 2016 Tentang Standar Proses Pendidikan Dasar dan Menengah. Jakarta: Permendikbud.

Permendiknas. (2007). Permendiknas RI Nomor 41 Tahun 2007 Tentang Standar Proses Pendidikan Dasar dan Menengah. Jakarta: Permendiknas.

Rusman. (2012). Model-model Pembelajaran Mengembangkan Profesionalisme Guru. Jakarta: PT. Raja Grafindo Persada.

Sugiyono. (2018). Metode Penelitian Kuantitatif, Kualitatif dan R\&D. Bandung: Alfabeta.

Surat Edaran No. 4 Tahun 2020 Tentang Pelaksanaan Kebijakan Pendidikan dalam Masa Darurat Penyebaran Coronavirus Disease (COVID-19).

Trianto. (2010). Pengembangan Model Pembelajaran Tematik. Jakarta: Prestasi Pustaka.

Trianto. (2011). Model Pembelajaran Terpadu Konsep Strategi dan Implementasinya dalam Kurikulum Tingkat Satuan Pendidikan (KTSP). Jakarta: Bumi aksara.

Wijayanti, S. (2009). Model Pembelajaran Kooperatif Tipe STAD (Student Teams Achievement Division) untuk Meningkatkan Hasil Belajar Matematika pada Siswa Kelas IV SDN 3 Bugel Kedung Jepara. Semarang: Universitas Negeri Semarang. 